\title{
TIPIFICACIÓN DE LOS SISTEMAS DE PRODUCCIÓN AGRÍCOLA Y LA PERCEPCIÓN DE LA VARIABILIDAD CLIMÁTICA EN ANZOÁTEGUI, VENEZUELA
}

\author{
Olivares, B.O. ${ }^{1 ;}$ ZINGARETTI, M.L. ${ }^{2}$; \\ Demey Zambrano, J.A. ${ }^{3}$ \& Demey, J.R. ${ }^{\dagger 4}$
}

\begin{abstract}
RESUMEN
En el trópico, los agricultores son considerados como netos observadores de la naturaleza, conocen muy bien los cambios asociados a la variabilidad climática y aunque la modernidad ha ido modificando sus prácticas, ellas siguen íntimamente ligadas a estos ciclos. El objetivo de esta investigación fue tipificar los sistemas de producción agrícola y describir la percepción de la variabilidad climática en territorios rurales de Anzoátegui, Venezuela. Se aplicó el análisis de componentes principales no lineal, análisis de conglomerados y evaluación de tablas de contingencias, mediante 100 encuestas realizadas al azar a productores agrícolas. El estudio mostró la tipificación de tres grupos de productores, donde las principales variables discriminadoras son las pertenecientes al componte socio-económico y las variables del componente climático no ejercieron una influencia de peso en la discriminación. Sin embargo, se pudo identificar que todos los agricultores reconocen el fenómeno de la variabilidad climática y lo perciben como un problema nacional y global que afecta negativamente la actividad económica. Adicionalmente, existe una percepción generalizada sobre la variabilidad climática en los últimos años la cual fue explicada a través de la ocurrencia de fenómenos naturales: sequia meteorológica, excesos de agua y erosión hídrica.
\end{abstract}

Palabras clave: variabilidad climática, agricultura, territorio.

1.- Investigador. Programa Iberoamericano de Doctores en Agroalimentación de la Universidad de Córdoba (UCO), Andalucía, España. Teléfono: (+58) 424-3173568. Correo: barlinolivares@gmail.com

2.- Docente- investigador. IAPCBA-IAPCH, Universidad Nacional de Villa María, Córdoba, Argentina.

3.- Investigador. Doctorando del Departamento de Estadística, Universidad de Salamanca, España.

4.- Investigador Prometeo SENESCYT, Escuela Superior Politécnica del Litoral (ESPOL), Ecuador. † 07/2016. Manuscrito recibido el 18 de octubre de 2016 y aceptado para su publicación el 8 de marzo de 2017. 


\begin{abstract}
Typification of agricultural production systems and the perception of climate variability in Anzoátegui, Venezuela.

In the tropics, farmers are considered net observers of nature, are well aware of the changes associated with climate variability and although modernity has been modifying their practices, they remain closely linked to these cycles. The objective of this research was to typify agricultural production systems and to describe the perception of climatic variability on rural territories of Anzoátegui, Venezuela. Non-linear main component analysis, cluster analysis, and contingency table evaluation were applied through 100 surveys randomized to agricultural producers. The study showed the typification of three groups of producers, where the main discriminatory variables are those belonging to the socio-economic component and the variables of the climatic component did not have a significant influence on the discrimination. However, it was possible to identify that all farmers recognize the phenomenon of climate variability and perceive it as a national and global problem that negatively affects economic activity. In addition, there is a general perception about climatic variability in recent years, which was explained through the occurrence of natural phenomena: meteorological drought, excess water and water erosion.
\end{abstract}

Key words: climatic variability, agriculture, territory.

\section{INTRODUCCIÓN}

El clima depende de un importante número de factores atmosféricos y oceánicos que interactúan en diferentes escalas, por ello los patrones de comportamiento de los fenómenos meteorológicos (tormentas, sequias, entre otros) y de las variables climatológicas como la precipitación tiene un impacto directo y heterogéneo en la distribución de la biodiversidad, la provisión de servicios ecosistémicos y las actividades humanas (11; 12; 24).

$\mathrm{Al}$ respecto, desde hace mucho tiempo, se ha venido estudiando la alteración espaciotemporal de dichos patrones del comportamiento climático y en torno a esto, el conocimiento científico ha puntualizado y demostrado que una de sus principales causas es la ocurrencia e intensidad de los fenómenos de la variabilidad climática ocasionados por el fenómeno El Niño Os- cilación del Sur (ENSO) (15; 22).

No obstante, se tiene establecido que el impacto de las fases extremas de la variabilidad climática en la sociedad no ha sido homogéneo dado que existen grupos y sectores con mayor o menor grado de vulnerabilidad (24); por ejemplo en Latinoamérica la intensidad y ocurrencia de eventos climáticos catastróficos afectan de manera más dramática a territorios rurales.

La explicación del clima mediante la conceptualización de los fenómenos variables de la atmosfera y su interrelación en varias escalas con el mar y el continente, ha sido el enfoque por parte de las ciencias naturales durante todo este tiempo (9). Sin embargo, considerando el enfoque de las ciencias sociales, el clima es el resultado de la forma en que los individuos perciben, se apropian e interpretan los eventos meteorológicos y climáticos que ocurren en su entorno. 